\title{
Landslide hazard zonation mapping using frequency ratio and fuzzy logic approach, a case study of Lachung Valley, Sikkim
}

Rathinam Anbalagan, Rohan Kumar*, Kalamegam Lakshmanan, Sujata Parida and Sasidharan Neethu

\begin{abstract}
Background: Sikkim Himalaya is under consistent distress due to landslides. Abrupt thrust on infrastructure development in the valley regions of Sikkim Himalaya has led to a need for a prior planning to face landslide hazard. A comprehensive study for the identification of landslide hazard zones using landslide frequency ratio and fuzzy logic in GIS environment has been presented for the Lachung valley, Sikkim, India, where a number of hydroelectric projects are proposed.

Temporal remote sensing data was used to generate significant landslide causative factors in addition to landslide inventory. Primary topographic attributes namely slope, aspect and relative relief were derived from digital elevation model. Landslide frequency ratio approach was adopted to correlate landslide causal factors with landslide incidences. Further, fuzzy logic method was used for the integration of landslide causative factors in order to delineate the landslide hazard zones. Fuzzy memberships were derived from the landslide frequency ratio values. Different gamma values were used in fuzzy gamma integration process, which resulted different landslide hazard index maps. Receiver operating characteristic curves were prepared to analyze consistency of the resulting landslide hazard index maps.
\end{abstract}

Results: Landslide frequency ratio values have emphasised the importance of factors/classes in landsliding. High slope angle $\left(35^{\circ}-45^{\circ}\right)$, very high slope category $\left(>45^{\circ}\right)$, High and very high relative relief categories; south, southeast and southwest aspects; drainage and lineaments buffer range of 0-50m, 50-100m and 100 to 150m; quartzite/ garnet schist and migmatite type of lithology; Sandy loam and Rock/loam classes of soils; fallow land and sparse vegetation classes of land use/land cover were found to be associated with landsliding. Five landslide hazard zonation maps with each comprising five relative landslide hazard zones namely; very low, low, moderate, high and very high hazard zones were prepared by using five fuzzy gamma operators. Maps indicated that steep talus slopes, close proximity to drainages, ridges and spars fall under high hazard zones. Settlement areas were observed in low to moderate hazard zones. Very high hazard zones were observed in steep slopes, cliffs and cut slopes excavated for the roads. Low hazard zones were observed in agricultural terraces and permafrost areas.

Conclusions: Hence it can be concluded that landslide causative factor's integration using fuzzy logic has yielded good results for Lachung valley. Frequency ratio method for determination of fuzzy membership value has reduced subjectivity in the model. The final LHZ map ( $\gamma=0.92)$ can be used for the planning of future infrastructure, settlement and ecological development in Lachung region.

Keywords: Fuzzy logic; Landslide hazard zonation; Frequency ratio

* Correspondence: rohananadi@yahoo.com

Department of Earth Sciences, Indian Institute of Technology, Roorkee, Uttarakhand, India 


\section{Background}

Landslide is a result of a wide variety of geo-environmental processes, which include geological, meteorological and human factors. The main factors which influence landslides were discussed by Varnes (1984) and Hutchinson (1995). Most important inherent factors are bedrock geology (lithology, structure, degree of weathering), geomorphology (slope gradient, aspect, and relative relief), soil (depth, structure, permeability, and porosity), land useland cover, and hydrologic conditions. Landslides are triggered by many extrinsic causative factors such as rainfall, earthquake, blasting and drilling, cloudburst, flash-floods (Anbalagan 1992). Present study area is a part of Sikkim Himalaya, which is consistently subjected to landslides during monsoon season. The Himalaya has highly undulating terrain, which is witnessing ongoing orogeny. In addition to that, during monsoon period the present area receives high precipitation. In this part of Sikkim Himalaya, a number of hydroelectric projects are in planning or construction phase and it has substantially increased the anthropogenic activities. Combination of inherent, external and orogenic factors has made this terrain highly vulnerable to landslides. A landslide hazard zonation (LHZ) map is prepared in advance to facilitate mitigation strategies in the wake of any landslide hazard. It provides a prior knowledge of landslide probable zones on the basis of a set of geo-environmental factors suitable for landslides locally. Assumption of LHZ is based on an analogy that the future landslide is expected on those locations which has same set of geo-environmental conditions as that of past and present landslide locations (Varnes 1984; Kanungo et al. 2009a). Choices of factors depend upon the exhaustive field work, data availability and professional experience. Advent of machine learning, fast computation packages, easy data availability and GIS has propelled the landslide hazard research to a new high. The outcome can be seen in terms of the quantum of literature regarding landslide hazard available at present. A number of terms such as landslide hazard zonation, landslide susceptibility mapping (LSM), landslide hazard mapping (LHM), landslide susceptibility zonation (LSZ), landslide probability etc. are in practice (Varnes 1984; Anbalagan 1992; Gupta et al. 1999; Arora et al. 2004; Brabb 1984; Guzetti et al. 1999; Lee et al. 2002;Ayalew and Yamagishi 2005; Mathew et al. 2007; Yalcin 2008; Yilmaz 2009; Pachauri and Pant 1992; Guzzetti et al. 2005; Van Westen et al. 2006; Lee and Pradhan 2007; Dahal et al. 2008; Dahal et al. 2009; Clerici et al. 2002; Saha et al. 2005; Kanungo et al. 2006; Gupta et al. 2008; Mathew et al. 2009; Chauhan et al. 2010; Ohlmacher 2007) for the landslide hazard related studies. Coinfusion still prevails among the researchers about the choice of the use of the term for landslide hazard studies. Varnes (1984) defined the term 'Zonation' in context of landslide. It applies in general terms to division of the land surface into areas and ranking these areas according to degree of actual or potential hazard from landslides or other mass movement on slopes. Landslide hazard is considered under the natural hazard category, which is defined as the probability of occurrence within a specified period of time and within a given area of potentially damaging phenomenon (Varnes 1984). In 1980s, 1990s and early 2000s, a number of authors used LHZ mapping (Gupta and Joshi 1990; Gupta and Anbalagan 1997; Nagarajan et al. 1998; Saha et al. 2002). Another term 'landslide susceptibility', in this context was given as spatial probability of occurrence of landslides based on a set of geo-environmental factors (Brabb 1984; Sarkar and Kanungo 2004; Lee and Sambath 2006; Kundu et al. 2013; Kayastha et al. 2013). Some authors are using the term 'landslide hazard mapping' in accordance with the definition of natural hazard given by UNO. Temporal factors such as rainfall, earthquake, and temperature variations etc. has been considered in landslide hazard mapping studies (Guzzetti et al. 2006; Pradhan et al. 2010; Dahal et al. 2012). Landslide susceptibility zonation (LSZ) is a compromise term and is practiced now a day's very often (Kanungo et al. 2009a). In the present study LHZ, LSM and LSZ has been perceived as the same.

In LHZ studies, remote sensing along with GIS provides great advantages. Remote sensing images are helpful in factor characterization and landslide inventory mapping. Temporal capability of remote sensing imageries are of a great help in acquiring past and present landslide incidences locally which further has a great significance in LHZ. GIS is very effective in data handling, manipulation and statistical measures. A number of methodologies are in practice for the identification of landslide hazard zone. Broadly, it can be classified into three groups namely, qualitative, semi-quantitative and quantitative method. In qualitative methods, scores are assigned to factors on the basis of professional knowledge. Semi quantitative methods assume weights and ranking on the basis of logical tools such as AHP, fuzzy logic and weighted linear combination (WLC). Quantitative methods are landslide inventory driven statistical methods and it considers association of landslide factors with landslide inventory. Based on landslide densities present in factor classes, weights/ratings are calculated mathematically. It can further be divided into bivariate and multivariate methods. Another quantitative method is the deterministic slope instability mapping, which is based on the geotechnical properties of the particular slope. Detailed review of the above mentioned methodologies can be found in the works of Guzetti et al. (1999), Aleotti and Chowdhury (1999), Kanungo et al. (2009a) and Pardeshi et al. (2013). LHZ techniques have been applied in Himalayan region by a number of authors. LHEF (Landslide Hazard Evaluation Factor) based LHZ was carried out by Anbalagan (1992), 
Landslide hazard mapping based on geological attributes (Pachauri and Pant 1992), GIS based landslide hazard zonation (Gupta et al. 1999), integrated approach for landslide hazard zonation (Sarkar and Kanungo 2004) and GISbased statistical landslide susceptibility zonation (Saha et al. 2005). Some authors adopted other techniques namely landslide hazard zonation based on meso scale for town planning (Anbalagan et al. 2008), fuzzy logic based LSZ mapping (Kanungo et al. 2006; Champatiray et al. 2007), predictive modeling of landslide hazard in lesser Himalaya by Dahal et al. (2008). Several quantitative and semiquantitative techniques were applied for landslide susceptibility/hazard modelling in Himalayan terrain. Logistic regression technique for data integration of geoenvironmental factors (Das et al. 2010), empirical modelling of landslide susceptibility in the Darjeeling Himalayas (Ghosh et al. 2011) and several others (Das et al. 2012; Kayastha et al. 2013; Kundu et al. 2013).

Lachung valley is physiographically narrow and elongated and it forms a crescent shape, which provides suitable conditions for trapping the nimbus clouds in the narrow gullies leading to cloud burst conditions. Numerous instances of cloud bursts or concentrated rain fall is commonly reported in this valley, which often results landslides and consequent transportation of huge quantum of debris down the slope. These debris materials, deposited by the side of the river course forming cones of debris. It is a striking factor that successive cones of debris are seen throughout the valley by the side of Lachung river course. The width of the debris cones are more on the right bank as compared to the left bank. This has resulted in a continuous presence of debris materials on both sides of the river course with rocks exposed much away from the river in the entire length of the basin Lachung. Major settlements are situated on these debris cones which are very prone to mass movements during the rainfall. Lachung valley is drained by the river Lachung Chu which is a major tributary of the Teesta river. A number of hydroelectric power plants are in construction phase in the Lachung and Teesta basin (just downstream to Lachung basin). In view of the existing settlements, infrastructures and upcoming infrastructures in the region, landslide hazard zonation is a necessity. In this paper, fuzzy logic technique was used to integrate the causative factors of landslide. Fuzzy membership values were derived from landslide frequency ratio. The frequency ratio is a ratio between the occurrence and absence of landslides in each cell/class of causative factors (Lee and Sambath 2006). A fuzzy membership value has a range $(0,1)$, where 0 is for the minimum fuzzy relation and 1 is for maximum. A membership value between 0 and 1 indicate the degree of fuzzy relationship. Fuzzy gamma operator was selected for the integration of factors using five different gamma values. ROC curves were prepared to validate the resulting maps.

\section{Study area}

The Lachung valley is located in the upper north-eastern reaches of Teesta river in Sikkim state of India. It has central longitude/latitude value of $88.65^{\circ} \mathrm{E}$ and $27.61^{\circ} \mathrm{N}$. The valley has temperate climate in the lower reaches of the valley, whereas high mountainous region in the north is characterized by low temperature Tundra type of climate. The valley receives an average monthly rainfall of $52 \mathrm{~mm}$ and also snowfall in the month of December, January and occasionally in the month of March. Figure 1 shows the location of the study area.

\section{Geological setting}

An overview of the area indicates that the Eastern Himalaya covers the Sikkim-Darjeeling-Bhutan and Arunachal Pradesh sectors, extending from the eastern Nepal to Western Burma. Higher Himalaya is a zone of crystalline rocks dividing two distinct lithofacies association in the South and the North. It is designated as the Axial belt. The Northern zone comprising the Tethyan PalaeoMesozoic sedimentary sequence forms the Trans- Axial belt. To the south of the Axial belt occurs the Inner belt, comprising thrust sheets of Proterozoic-Upper Palaeozoic formations, while the foothill belt is represented by paraautochthonous Siwaliks. This geological framework is valid for the entire Eastern Himalaya, upto the Lohit District of Arunachal Pradesh, where the geological picture does not conform to this general scheme. The stratigraphic sequence provided by GSI indicates that the Lachung region from South to North is occupied by Gondwana, Daling, Chungthang and Central Crystalline Gneissic group of rocks (Figure 2). Rock types belonging to Chungthang Formation and Kanchenjunga gneiss of Central Crystallines of Higher Himalaya occupy in and around the area of study. These rocks are seen in Chungthang area at the mouth of the basin. In the central area, the Kanchanjunga group of rocks comprising gneisses are exposed. The contact between the two is reported to be thrusted. Due to complex folding, gneissic and schistose bands are intricately folded with meta-sedimentary units. In general, the rock type trends in NW-SE to N-S direction dipping towards northeast to east direction.

\section{Data preparation}

A spatial data set containing landslide causative factors namely, slope, aspect, relative relief, lithology, distance to photo-lineament, distance to drainage, land/use land/cover (LULC) and soil cover was used to apply fuzzy logic method for LHZ. LISS-IV image of 5.6 meter spatial resolution was used to generate LULC (Figure 3), photolineament and landslide inventory of the Lachung valley. Landsat ETM+, ASTER and IRS LISS-IV DATA were further used to delineate landslide incidents by means of visual image interpretation. Cartosat-1 DEM of 2.5 meter spatial 


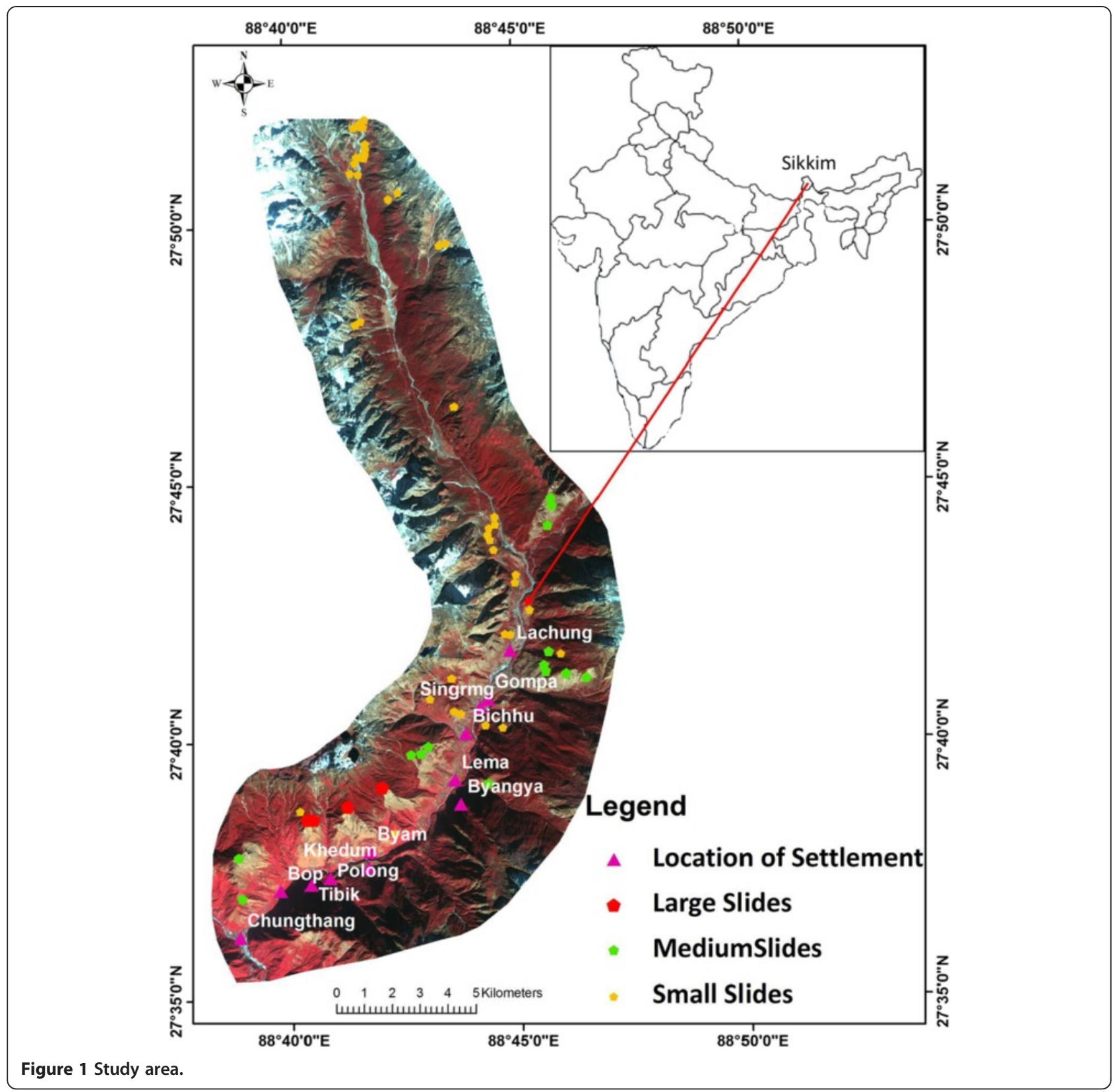

resolution was used to generate drainage network, slope, aspect and relative relief maps. Ancillary data such as geological map, topographic map, soil map and landslide inventory map of varying scales were obtained from different concerning departments. All data set were rasterized to $5 \mathrm{~m} \times 5 \mathrm{~m}$ grid cell. Finally a spatial data set of $5009 \mathrm{col}-$ umns and 6239 rows were prepared. Table 1 shows different data types used in present study. Figure 4 refers to some of the data layers worked out in this study.

\section{Lithology}

Rock types of Lachung valley belongs to Chungthang Formation and Kanchenjunga gneiss of Central Crystallines of Higher Himalaya. Chungthang Formation comprises quartz-biotite schist, calc-silicate rocks and graphite schists. The quartzites at places have intrusions of amphibolites and pegmatite veins. These rocks are seen in Chungthang area at the mouth of the valley. These rocks are less prone to landslides. In the Lachung area, the Kanchenjunga group of rocks, comprising gneisses is exposed. These rocks are hard, compact and well jointed and at places intruded by tourmaline granites and pegmatite. The rock types are represented mainly by high-grade metamorphic of central crystalline gneisses complex. In general these rocks are also less prone to weathering. The contact between the two is reported to be thrusted. (Acharya and Shastry 1979; Ray 


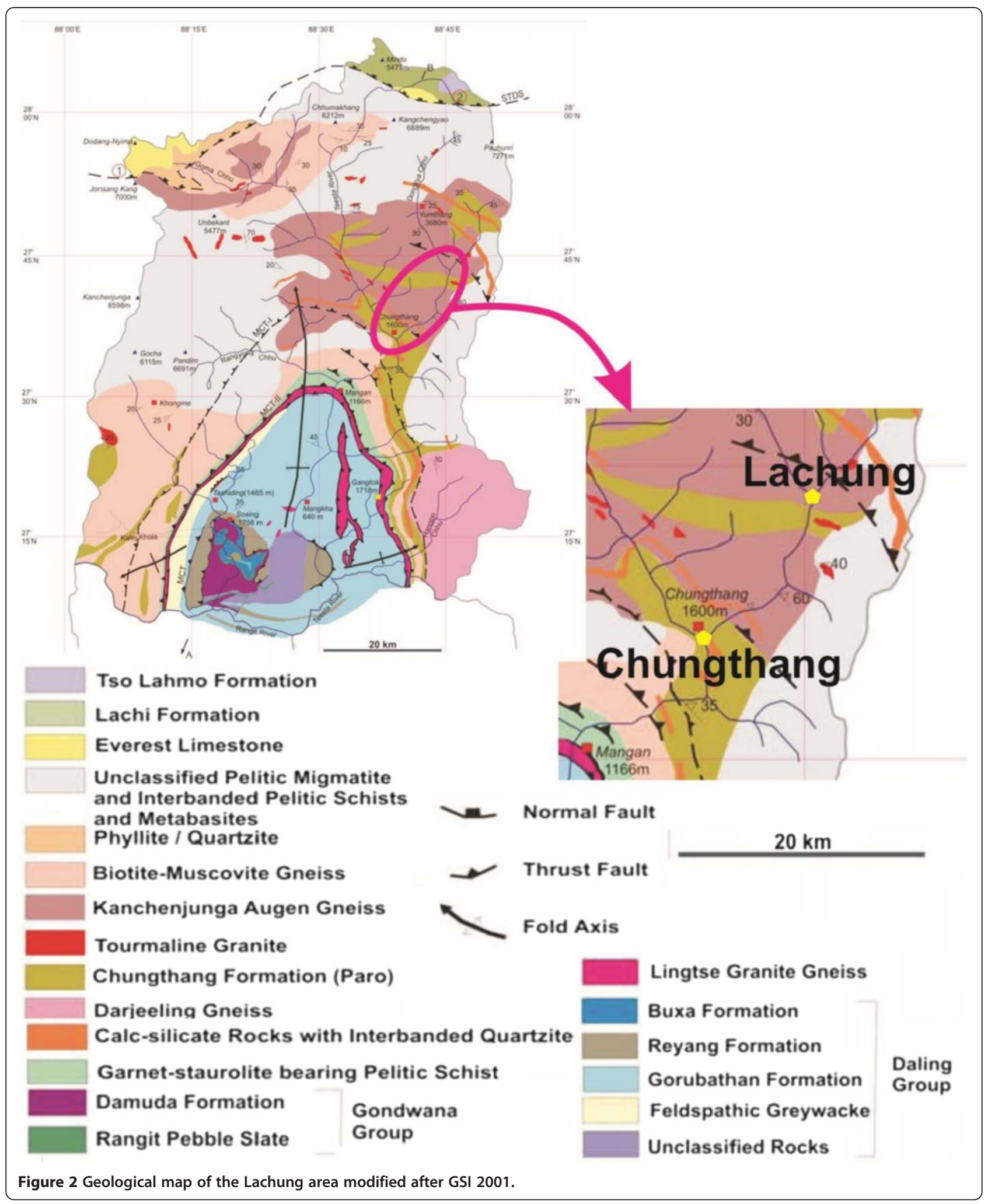

1976; Sinha-Roy 1982). Due to complex folding, gneissic and schistose bands are intricately folded with metasedimentary units. In general, the rock type trends in NW-
SE to N-S direction dipping towards northeast to east direction. The implications of tectonics and lithological attributes have been considered in formulating concepts as 


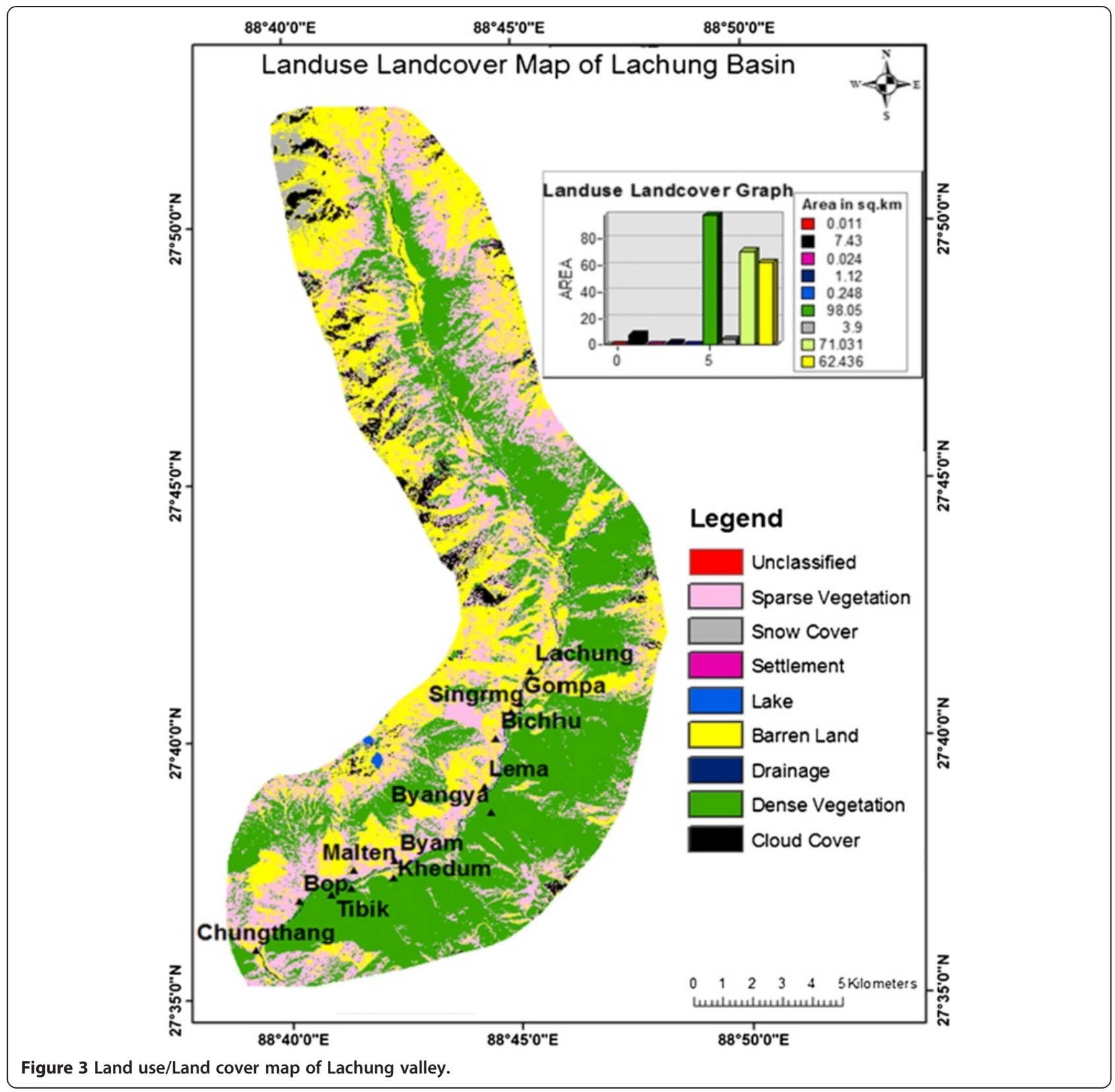

regards to landslides in Sikkim Himalayas. Geological map of the area is presented in Figure 2.

\section{Land use land cover}

Image classification resulted into 8 land/use land/cover classes namely, dense vegetation, sparse vegetation, lake, drainage, settlement, cloud-cover, fallow/barren land, and snow cover (Figure 3). It is found that basin in general has a good vegetation cover with thick vegetation covering an area of about $98 \mathrm{sq} \mathrm{km}$. It is mainly concentrated on the left bank of the Lachung river in the lower reaches between Chungthang and Lachung. On the right bank the thick vegetation is seen adjoining to the river up to
Lachung with patches of sparse vegetation and barren land. A part of middle and top slopes close to the ridge are generally barren in nature due to snow cover. On the left bank the top slopes close to the ridge are barren in the upper reaches of the basin. Sparse vegetation is seen as patches and well distributed within the basin.

\section{Soil Cover}

Soils of the Lachung valley are mainly constituted of sandy loam, loamy sand, sandy clay loam and sandy rocky loam. These soils are prone to sheet erosion, gully erosion and creeping. 
Table 1 Data used in present study

\begin{tabular}{|c|c|c|c|}
\hline Data type & Sensor & Scale & Data derivative \\
\hline \multirow[t]{3}{*}{ Image data } & IRS LISS-IV & $5.6 \times 5.6 \mathrm{~m}$ grid & Land/use Land/cover \\
\hline & ASTER & $15 \mathrm{~m} \times 15 \mathrm{~m}$ grid & Photo-lineament \\
\hline & Landsat ETM+ & $30 \mathrm{~m} \times 30 \mathrm{~m}$ grid & Landslide inventory \\
\hline \multirow[t]{4}{*}{ DEM } & Cartosat 1 & $2.5 \mathrm{~m} \times 2.5 \mathrm{~m}$ grid & Slope \\
\hline & & & Aspect \\
\hline & & & Relative Relief \\
\hline & & & Drainage \\
\hline \multirow[t]{4}{*}{ Ancillary data } & Published geological map (GSI) & $1: 50,000$ & Geology map \\
\hline & Published soil map & 1: 50,000 & Soil map \\
\hline & Published topographic map (SOI) & 1: 50,000 & Topographic map \\
\hline & Historical landslide inventory & 1: 50,000 & Landslide Inventory \\
\hline
\end{tabular}

\section{Topographic attributes}

Aspect is an important factor considered in LHZ (Nagarajan et al. 1998; Saha et al. 2002; Kanungo et al. 2009b) studies. Aspect is the direction a slope faces with respect to north. Aspect determines the effect of solar heating, soil moisture and dryness of air (Yalcin 2008). Aspect map of the area was prepared on the basis of DEM manifesting nine classes namely, flat $(-1)$, north $\left(0^{\circ}-22.5^{\circ}\right.$ and $\left.337.5^{\circ}-360^{\circ}\right)$, northeast $\left(22.5^{\circ}-67.5^{\circ}\right)$, east $\left(67.5^{\circ}-112.5^{\circ}\right)$, southeast $\left(112.5^{\circ}-157.5^{\circ}\right)$, south $\left(157.5^{\circ}-202.5^{\circ}\right)$, southwest $\left(202.5^{\circ}-247.5^{\circ}\right)$, west $\left(247.5^{\circ}\right.$ $\left.292.5^{\circ}\right)$ and northwest $\left(292.5^{\circ}-337.5^{\circ}\right)$ (Figure 4b). Slope angle substantially impact the landslide incidences (Kanungo et al. 2006; Gupta et al. 2008; Dahal et al. 2009). Slope map was prepared covering six classes: very low/flat $\left(0^{\circ}-5^{\circ}\right)$, low $\left(5^{\circ}-15^{\circ}\right)$, moderate $\left(15^{\circ}-25^{\circ}\right)$, moderately high $\left(25^{\circ}-35^{\circ}\right)$ and high $\left(35^{\circ}-45^{\circ}\right)$ and very high $\left(>45^{\circ}\right)$ (Figure $\left.4 \mathrm{~d}\right)$. Relative relief is the difference between maximum and minimum elevation point within a facet or area and it is widely used in LHZ model (Gupta et al. 1999; Saha et al. 2005; Kanungo et al. 2009b). In the present study, relative relief was found to be varying between 0 to $320 \mathrm{~m}$. Following five classes of relative relief: very low relief $(0-30 \mathrm{~m})$, low relief $(30 \mathrm{~m}-$ $60 \mathrm{~m})$, moderate relief $(60 \mathrm{~m}-100 \mathrm{~m})$, high relief $(100 \mathrm{~m}-$ $150 \mathrm{~m})$ and very high relief $(>150 \mathrm{~m})$ were considered for landslide LHZ study (Figure 4c).

\section{Photo-lineaments}

Linear geological discontinuities can be delineated from multispectral image and DEM and are called photolineament. Landslides are associated with the proximity to photo-lineament (Gupta et al. 1999). A distance to lineament map (also called lineament buffer map) covering $50 \mathrm{~m}$, $100 \mathrm{~m}, 150 \mathrm{~m}$ and $200 \mathrm{~m}$ distances was prepared complying with field evidences of landslides. The overall lineament pattern of Lachung basin shows a nearly similar trend as that of drainage pattern. Distance from these structural features have relative influence on the landslide, accordingly buffer map is prepared for landslide hazard zonation.

\section{Landslide inventory}

Landslide inventory map is prepared from satellite imageries and field investigations. Temporal ASTER and IRS LISS-IV remote sensing data of pre and post earthquake is used to map the landslides. Based on the size, they have been divided visually into large, medium and small. These landslides are shallow in nature (Figure 4a). Since the depth of the slides is limited to few meters it is mainly affecting the overlying debris materials and a small part of the rocks below which seems to be intact. The resultant debris can be seen lying on the slope below. A few medium size slides are seen mainly in the middle portions of the valley. The small landslides are commonly seen in many places, though they seem to be concentrated in the lower reaches where the debris cone materials are present. Moreover, debris materials are consistently present on either side of the river. Hence wherever the river takes sharp turns locally the toe erosion had resulted in a series of shallow landslides by the side of the river on either bank. Landslide data is used for the validation of landslide hazard zonation map.

\section{Methods}

\section{Landslide casual factors and data processing}

In the present study, fuzzy logic technique was used to perform LHZ mapping. First step was the preparation of landslide causative factor layers. It is very common to assume causal factors to predict landslide occurrences in the absence of any universally defined set of factors. The assumption behind this is that future landslides will occur under similar conditions as past and present landslides (Lee and Talib 2005). In the present study, causal factors included remote sensing imagery derived land/ use land/cover map, photo-lineament map and DEM derived slope, aspect and relative relief map. LULC of the present area was extracted by applying supervised classification of LISS -IV image in ERDAS Imaging software. Photo-lineament was extracted from visual 

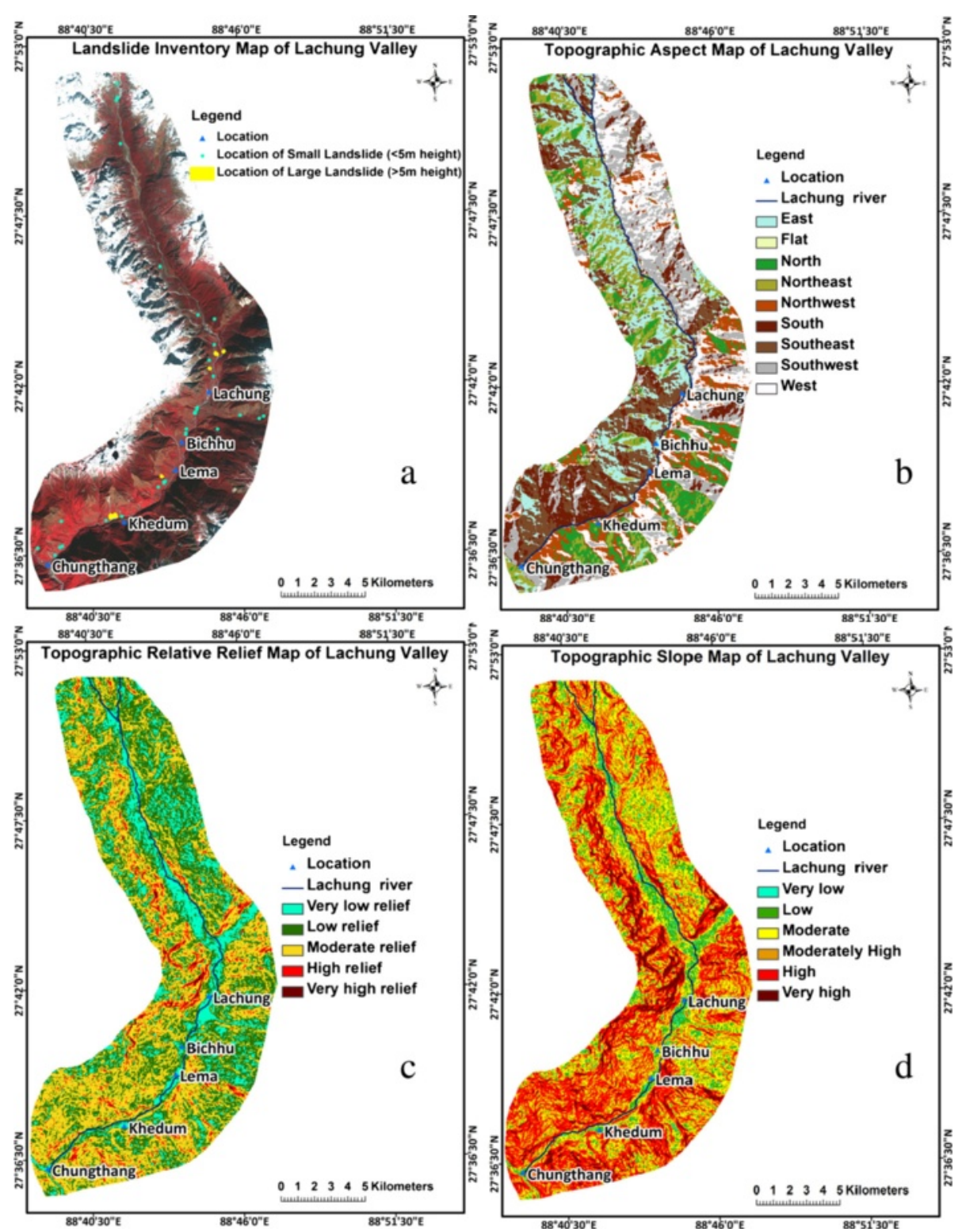

Figure 4 Refers to a) Landslide inventory, b) Aspect, c) Relative relief, d) Slope map of Lachung valley.

interpretation of remote sensing imagery. Proximity to drainage and photo-lineament are important causative factors (Gupta et al. 1999). In this study distance to photo-lineament and distance to drainage layer was used as causal factors. Furthermore, ancillary data which includes geology and soil maps were co-registered with imagery derived data in GIS environment and vector layers were generated.

\section{Fuzzy modeling}

In the next step, data integration was performed using fuzzy logic technique. Fuzzy set theory was introduced by Zadeh (1965). It facilitates analysis of non-discrete natural processes as mathematical formulae (Zimmermann
1996). According to this theory, membership value of elements $(\mathrm{x})$ has varying degree of support and confidence $(f(x))$ in the range $(0,1)$ (Ercanoglu and Gokceoglu 2002). A fuzzy set can be described by formula given below as

$$
\mathrm{A}=\left\{\mathrm{x}, f_{\mathrm{A}}(\mathrm{x})\right\}, \mathrm{x} \in \mathrm{R} .
$$

Where A is a fuzzy set, $\mathrm{x}$ is an element of universal set $\mathrm{R}$, and $f(\mathrm{x})$ is the fuzzy membership function. A crisp set range $(0,1)$ has either membership value of 1 or non-membership value of 0 whereas a fuzzy set inherit continuous membership in the range $(0,1)$. 
Table 2 Showing frequency ration and fuzzy membership values for different attributes

\begin{tabular}{|c|c|c|c|c|}
\hline Factors $\&$ attributes & Landslide grid\% & Total area grid\% & Frequency ratio & Membership function \\
\hline \multicolumn{5}{|l|}{ Geology } \\
\hline Quartzite/Garnet Schist & $11.00 \%$ & $5.40 \%$ & 2.02 & 0.181 \\
\hline Permafrost & $0.00 \%$ & $13.50 \%$ & 0 & 0 \\
\hline Migmatite/Biotite gneiss & $89.00 \%$ & $81.10 \%$ & 1.1 & 0.098 \\
\hline \multicolumn{5}{|l|}{ Soil type } \\
\hline Loam/sand & $0.00 \%$ & $0.54 \%$ & 0 & 0 \\
\hline Rock/loam & $9.50 \%$ & $6.60 \%$ & 1.44 & 0.129 \\
\hline Loam/rock & $6.82 \%$ & $20.70 \%$ & 0.33 & 0.029 \\
\hline Permafrost & $0.00 \%$ & $4.31 \%$ & 0 & 0 \\
\hline Sandy loam & $68.18 \%$ & $35.57 \%$ & 1.92 & 0.172 \\
\hline Sandy/clay loam & $14.09 \%$ & $28.89 \%$ & 0.49 & 0.044 \\
\hline Sandy/loam rock & $1.36 \%$ & $3.39 \%$ & 0.40 & 0.035 \\
\hline \multicolumn{5}{|l|}{ Relative relief } \\
\hline Very low (0-30 m) & $6.25 \%$ & $16.13 \%$ & 0.39 & 0.0349 \\
\hline Low (30-60 m) & $18.75 \%$ & $37.24 \%$ & 0.50 & 0.044 \\
\hline Moderate (60-100 m) & $50.00 \%$ & $40.97 \%$ & 1.22 & 0.109 \\
\hline High (100-150 m) & $18.75 \%$ & $5.10 \%$ & 3.68 & 0.329 \\
\hline Very high (>150 m) & $6.25 \%$ & $0.56 \%$ & 11.16 & 1 \\
\hline \multicolumn{5}{|l|}{ Slope category } \\
\hline $0^{\circ}-5^{\circ}$ (Very low) & $1.27 \%$ & $2.03 \%$ & 0.63 & 0.056 \\
\hline $5^{\circ}-15^{\circ}$ (Low) & $2.53 \%$ & $11.70 \%$ & 0.22 & 0.019 \\
\hline $15^{\circ}-25^{\circ}$ (moderate) & $8.86 \%$ & $20.61 \%$ & 0.43 & 0.038 \\
\hline $25^{\circ}-35^{\circ}$ (Moderately high) & $22.78 \%$ & $27 \%$ & 0.84 & 0.075 \\
\hline $35^{\circ}-45^{\circ}$ (High) & $45.57 \%$ & $31.20 \%$ & 1.46 & 0.130 \\
\hline$>45^{\circ}$ (Very high) & $18.99 \%$ & $7.46 \%$ & 2.55 & 0.228 \\
\hline \multicolumn{5}{|l|}{ Aspect } \\
\hline North & $4.83 \%$ & $0.8 \%$ & 0.16 & 0.015 \\
\hline Northwest & $10.18 \%$ & $3 \%$ & 0.294 & 0.026 \\
\hline West & $14.57 \%$ & $7 \%$ & 0.48 & 0.043 \\
\hline Southwest & $14.76 \%$ & $14 \%$ & 0.94 & 0.086 \\
\hline South & $10.76 \%$ & $40 \%$ & 3.71 & 0.33 \\
\hline Southeast & $16.10 \%$ & $20 \%$ & 1.24 & 0.11 \\
\hline East & $16.8 \%$ & $8.2 \%$ & 0.48 & 0.044 \\
\hline Northeast & $11.98 \%$ & 7 & 0.58 & 0.05 \\
\hline Flat & $0.0017 \%$ & 0 & 0 & 0 \\
\hline \multicolumn{5}{|l|}{ Lineament buffer } \\
\hline$>200 m$ & $56.25 \%$ & $61.23 \%$ & 0.92 & 0.082 \\
\hline $0-50 m$ & $15.00 \%$ & $10.39 \%$ & 1.44 & 0.129 \\
\hline $50-100 m$ & $7.50 \%$ & $10.56 \%$ & 0.71 & 0.063 \\
\hline $100 m-150 m$ & $6.25 \%$ & $9.42 \%$ & 0.66 & 0.059 \\
\hline $150 m-200 m$ & $15.00 \%$ & $8.40 \%$ & 1.79 & 0.160 \\
\hline \multicolumn{5}{|l|}{ Drainage buffer } \\
\hline$>200 \mathrm{~m}$ & $43.75 \%$ & $78.31 \%$ & 0.56 & 0.050 \\
\hline $0-50 m$ & $18.75 \%$ & $5.41 \%$ & 3.46 & 0.31 \\
\hline
\end{tabular}


Table 2 Showing frequency ration and fuzzy membership values for different attributes (Continued)

\begin{tabular}{|c|c|c|c|c|}
\hline $50-100 m$ & $10.00 \%$ & $5.84 \%$ & 1.71 & 0.153 \\
\hline $100 m-150 m$ & $8.75 \%$ & $5.12 \%$ & 1.7 & 0.152 \\
\hline $150 m-200 m$ & $18.75 \%$ & $5.30 \%$ & 3.54 & 0.317 \\
\hline \multicolumn{5}{|l|}{ LULC Type } \\
\hline Fallow/Barren Land & $53.75 \%$ & $26.36 \%$ & 2.04 & 0.182 \\
\hline Sparse Vegetation & $38.25 \%$ & $30 \%$ & 1.27 & 0.113 \\
\hline Dense Vegetation & $8 \%$ & $41.40 \%$ & 0.19 & .017 \\
\hline Settlement & 0 & $0.095 \%$ & 0 & 0 \\
\hline Snow cover & 0 & $1.65 \%$ & 0 & 0 \\
\hline
\end{tabular}

\section{Fuzzy membership determination using frequency ratio} approach

Landslide hazard zonation mapping requires determination of fuzzy membership function of causative factors. Fuzzy membership function can be determined subjectively or objectively. There is no universal approach available for the determination of fuzzy membership function (Champatiray et al. 2007). A suitable and universally acceptable approach may enhance information accuracy (prediction capability). For LHZ, several authors used knowledge based approach for assigning fuzzy membership function (Chung and Fabbiri 2001, Champatiray et al. 2007). Depending upon the data type (ordered or categorical) a membership function can be assigned quantitatively. In the present study, categorical factor layers were considered for fuzzy integration. Mathematical methods of fuzzy membership determination are not fit for categorical data. Landslide factors were compared with landslide inventory and a correlation between them were quantitatively analyzed by landslide frequency ratio method.

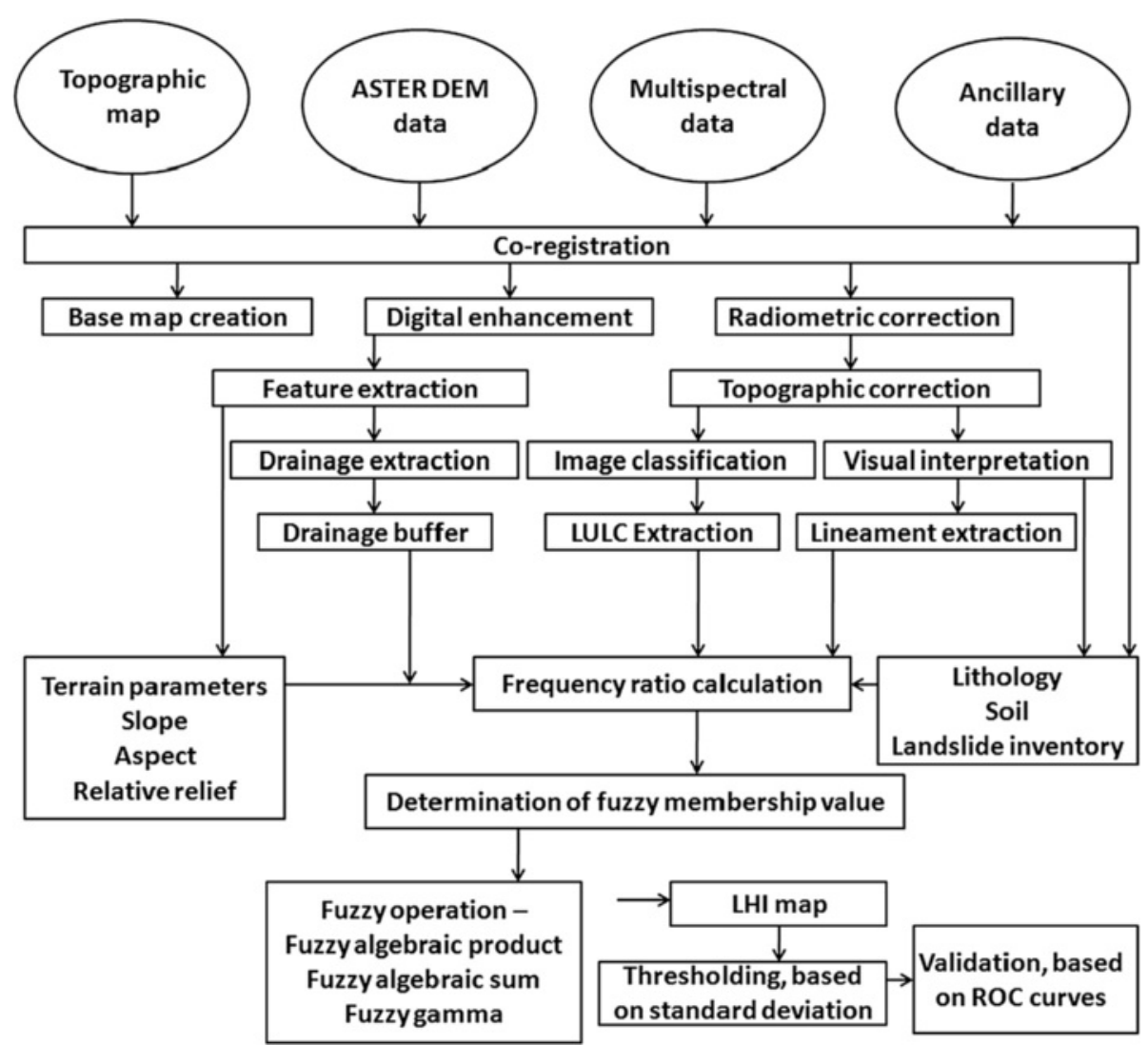

Figure 5 Methodology flowchart for LHZ mapping. 


\section{Landslide frequency ratio}

The assumption behind LHZ is that future landslides will occur under similar conditions as past and present landslides (Lee and Talib 2005). Following the same assumption, a relationship can be determined between landslides related casual factors with the landslide occurrences and nonoccurrences spatially. This relationship can be quantified using frequency ratio. Landslide frequency ratio can be calculated by the ratio of percent domain of a factor class and percent landslide in that class (Lee and Sambath 2006; Poudyal et al. 2010; Pradhan 2010; Pourghasemi et al. 2013). It follows the principle of conditional probability, in which if the ratio is $>1$ then there is a strong relationship between landslides and factor classes whereas ratio $<1$ represents weak relationship. Normalized value of landslide frequency ratio was used as fuzzy membership function by (Pradhan et al. 2010). In this study also, frequency ratio results were normalized in the range $(0,1)$. Table 2 refers to frequency ratio and fuzzy membership value of each attribute.

\section{Fuzzy integration/operation}

Next step of fuzzy logic technique is fuzzy operation. Fuzzy OR, fuzzy AND, fuzzy algebraic sum, fuzzy algebraic product and fuzzy gamma operator are important fuzzy operators (Chung and Fabbiri 2001). In case of fuzzy OR and fuzzy AND, only one of the contributing fuzzy set has an effect on the resultant value. The fuzzy algebraic sum and fuzzy algebraic product operators make the resultant set larger than, or equal to the maximum value and smaller than, or equal to the minimum value among all fuzzy sets respectively (Chi et al. 2002). Fuzzy gamma $(\gamma)$ operator calculates values which range between fuzzy algebraic product and fuzzy algebraic sum. Gamma $(\gamma)$ value has a range between 0 (No compensation) and 1(full compensation). Determination of optimum $\gamma$ value is dependent on the degree of compensation between two extreme confidence levels.

Choice of suitable fuzzy operator for the data integration is required to achieve optimum result in landslide prediction studies. Choice of a fuzzy operator depends upon the types of spatial data to be integrated (Choi et al. 2000). Fuzzy gamma operator was chosen to integrate factors using the formula given below:

$$
f_{\gamma}(\mathrm{x})=(\text { FuzzyAlgebraic Sum })^{\gamma} \times(\text { Fuzzy Algebraic Product })^{1-\gamma}
$$

$$
\text { Fuzzy Algebraic Product }=\prod_{i=1}^{n} R_{i}
$$
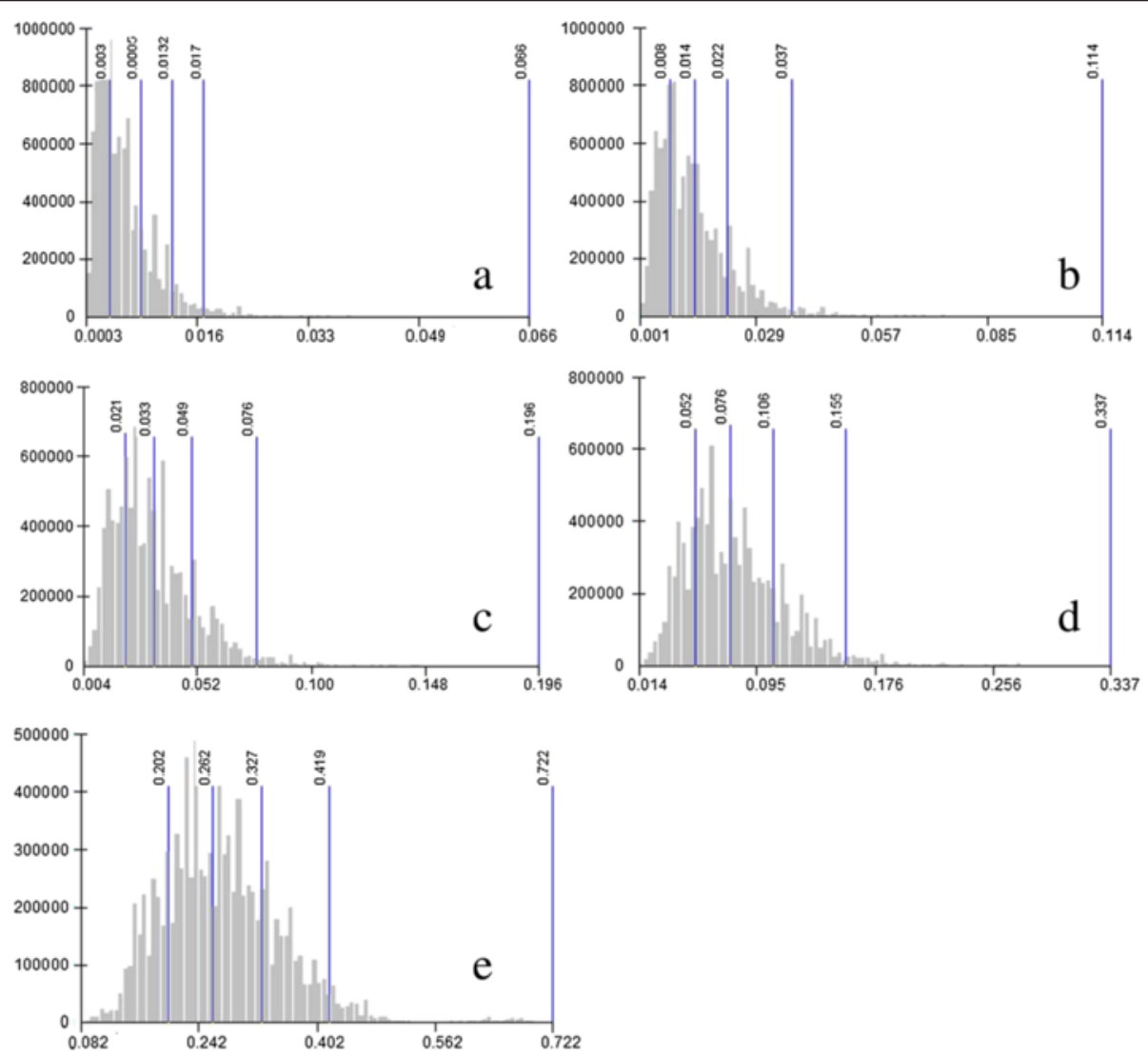

Figure 6 Threshold values chosen for classification of LSI map a) $\gamma=0.75, b) \gamma=0.8, c$ ) $\gamma=0.85$ d) $\gamma=0.92$, e) $\gamma=0.975$. 


$$
\text { Fuzzy Algebraic Sum }=1-\prod_{i=1}^{n}\left(1-R_{i}\right)
$$

where $\mathrm{x}$ denotes the membership functions and $R_{i}$ denotes fuzzy membership function of $i$-th map, $i=1,2 \ldots$ n. Using equation 2, 3 and 4 LHI maps were prepared. Further LHI maps were classified in five hazard zones namely, very low, Low, Moderate, high and very high hazed high hazard zones using Jenks natural break classifier in Arc GIS 10.1. Figure 5 refers to complete methodology flow chart.

\section{Result and discussion}

\section{Landslide Frequency Ratio}

Landslide frequency ratio was used as fuzzy membership function. Results of frequency ratio have been presented in
Table 2. Analysis of landslide frequency ratio indicates the importance of factors/classes on landslides. Topographic attributes are found to have good association with landslide incidences. Among the slope categories, high landslide frequency ratio is observed in high slope $\left(35^{\circ}-45^{\circ}\right)$ and very high slope category $\left(>45^{\circ}\right)$. In steep slopes, the weight of the possible mobilized material under gravity will be more as compared to a moderate slope. Shear strength being same in both the cases, a steep slope with more mobilizing force may fail early. High and very high relative relief categories have resulted in high frequency values. Frequency ratio of the relative relief categories also indicates the increasing tendency in very low relief to very high relative relief classes. High relative reliefs are surface manifestation of cliffs and ridges, which are often rendered unstable by the influence of triggering factors such as rainfall and

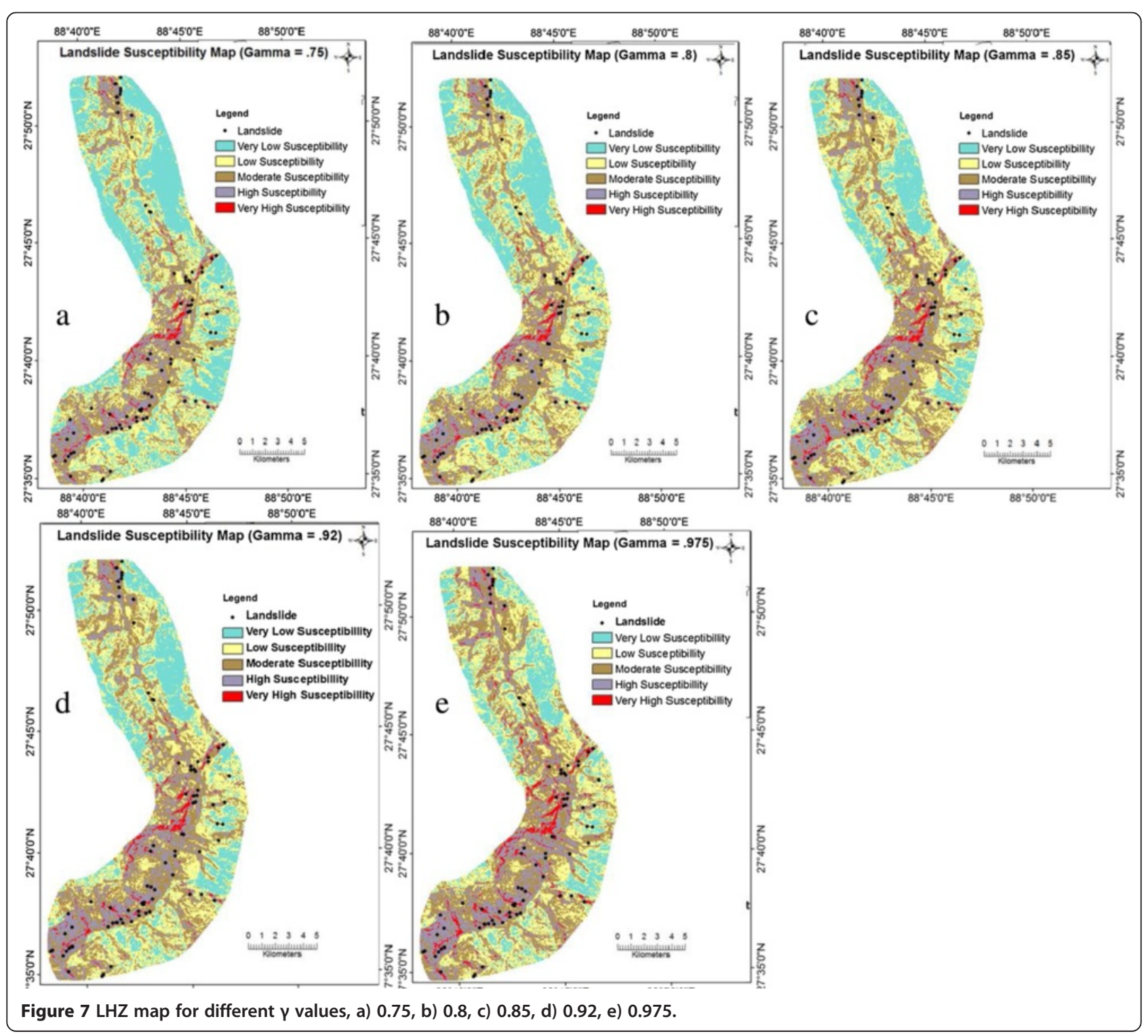


earthquakes. Topographic aspect is also found to be an important factor in this area. Very high frequency ratio; 3.71, 1.24 and 0.94 are found for south, southeast and southwest aspect respectively. Southern aspect of the study area, which is receiving excessive sun radiation and high rainfall, are more prone to landslides. In view of LHZ, drainage and lineaments buffer maps of , 0-50 m, $50-100 \mathrm{~m}, 100-150 \mathrm{~m}$, $150-200 \mathrm{~m}$ and $>200 \mathrm{~m}$ were prepared. Frequency ratio for the range: $0-50 \mathrm{~m}, 50-100 \mathrm{~m}$ and 100 to $150 \mathrm{~m}$ are found to be high in case of drainage buffer and it can be attributed to the stream bank erosion due to the river flow such as gulling, toe cutting which further leads to landslides. Lithology of the area belongs to different formations as mentioned in the previous section. Each formation is represented by characteristic rock type, which might govern landslide incidence. Frequency ratio results of geology layer have reflected that quartzite/garnet schist and migmatite are more prone to landslide in view of frequency ratio values. Among the soil categories, Sandy loam and Rock/ loam has resulted in high frequency value where as other categories resulted low values. Within the LULC classes, high landslide frequency value is observed in fallow land and sparse vegetation classes and can be attributed to the inherent physical properties of the LULC classes.

\section{Landslide Hazard Zonation}

LHZ maps were prepared by classifying LHI map. Each cell of LHI map contains hazard information in continuous form of range $(0,1)$. A statistical classification based on Jenk's natural breaks method was used for LHI maps. Natural Breaks classes are based on natural clustering inherent in the data. Class breaks are identified that best group similar values and that maximize the differences between classes (ESRI FAQ 2012). Five LHI maps were prepared by applying five different gamma values in fuzzy gamma operator function. LHI maps were further divided into five classes (very low, low, moderate, high and very high hazard zone) on the basis of natural break of LHI values. In all the five cases natural break points were taken as threshold value for the hazard zones (Figure 6). In the first case $(\gamma=0.75)$ LHI value was found to be varying between 0.00357 and 0.06635 . Threshold value of 0.003575 , $0.006332,0.01034,0.01863$, and 0.0663 were chosen on the basis of natural breaks to classify the LHI map into LHZ. In this case, $84.06 \mathrm{sq}$. $\mathrm{km}$. area was occupied by very low hazard zone, $69.77 \mathrm{sq}$. $\mathrm{km}$. area was under low hazard zone, $51.13 \mathrm{sq} . \mathrm{km}$. area found in moderate hazard zone, $32.82 \mathrm{sq} . \mathrm{km}$. area found in high hazard zone. In case of $\gamma$ value of 0.8 , LHI value was varying between 0.001166 and 0.114158 and threshold value of 0.00853 . 0.014475. $0.022638,0.03798$, and 0.11415 were chosen for LHZ. In case of $\gamma$ value of 0.85 , LHI values were varying from 0.004089 to 0.1963 . Threshold value of $0.02144,0.03390$, $0.0496,0.0768$, and 0.1963 were chosen to obtain LHZ map. In case of $\gamma$ value of 0.92 , LHI values were varying between 0.01432 to 0.3378 and threshold value of 0.05069 , 0.0754, $0.10637,0.1556$, and 0.3378 were chosen for hazard classes. In case of 0.975 , LHI values were found in the range of 0.08295 to 0.72214 and threshold values of $0.1947,0.25576,0.3211,0.4071$, and 0.7221. LHZ of five gamma cases are shown in Figure 7 . These results shows increasing trend of LHI values as the $\gamma$ value increases. Very high and high hazard area obtained in case of $\gamma$ value of 0.975 and 0.92 were larger in comparison to $\gamma$ value of

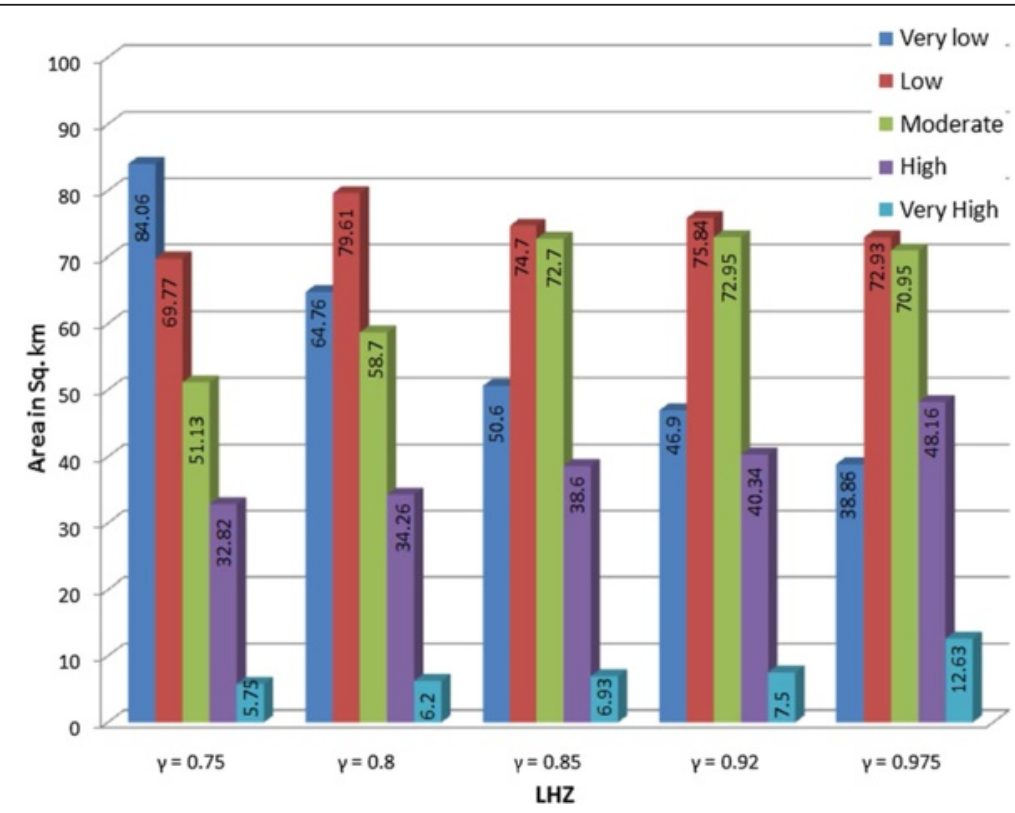

Figure 8 Bar chart showing area covered under different hazard zones for different gamma values. 
$0.75,0.8$, and 0.85 . Figure 8 shows the area occupied by hazard zones for different $\gamma$ values. Very high hazard area of 12.63 and $7.5 \mathrm{sq}$. km. was found in case of gamma values 0.975 and 0.92 respectively, whereas $5.75,6.2$ and $6.93 \mathrm{sq}$. km. area found for gamma values of $0.75,0.8$, and 0.85 . Figure 8 refers to area covered under different hazard zones for different gamma values selected for fuzzy integration. A judicious choice of gamma value: 0.92 was selected for the final LHZ. Results indicate that area occupied by debris cone (terraces), generally falls under moderate hazard zone, where as steep talus slopes fall under high hazard zone. High hazard zones are also observed in close proximity to drainages, ridges and spars. Settlement areas are generally situated on the flat terraces and are less prone to the landslides. On the contrary, these terraces are made up of RBM (River Bourne Materials) or debris and may be subjected to mass movements such as gullying, sheet erosion in case of intense rain. Very high hazard zones are generally found near the steep slopes, cliffs and cut slopes adjoining the roads. Low hazard zones are observed in agricultural terraces, settlement area and permafrost areas.

\section{Validation of Landslide Hazard Zonation Maps}

Prediction accuracy assessment was performed to obtain the consistency of LHZ. Accuracy of LHZ is the capability of map to delineate landslide free and landslide prone areas. Comparison of different models and model parameter variables can also be done from validation (Begueria 2006). Accuracy and objectivity depend on model accuracy, input data, and experience of earth scientist and size of the study area (Soeters and Van Westen 1996). Validation of landslide susceptibility/hazard zonation maps are mainly based on the confusion matrix or contingency table (Bonham-Carter 1994). Confusion matrix consists of the calculation of overlap areas between the two binary maps. For confusion matrix, continuous susceptibility/hazard maps are compared with the landslide inventory map. There are two types of error found in LHZ, 1) landslides may occur in areas that are predicted to be stable, and 2) landslides may actually not occur in areas that are predicted to be unstable (Soeters and van Westen 1996). Prediction accuracy of LHZ were performed on the basis of receiver operating characteristic (ROC) curves in the present study. The ROC curve technique is based on plotting model sensitivity, true positive fraction values calculated for different threshold values versus model specificity, true negative fraction values on a graph (Deleo 1993). Model sensitivity-true positive fraction is the ratio between correctly classified presence data and all presence data, while model specificity-true negative fraction is the ratio between correctly classified grid cells without landslides and all grid cells without landslide (Pradhan and Lee 2010). Area under the ROC curve has peak value of 1 for perfect prediction where as value near 0.5 suggests failure of the model. A comparison result of the present study is shown in Figure 9. It shows five different curves with varying degree of smoothness. LHZ for the gamma value of 0.92 shows better smoothness than other gamma values Figure 10. ROC curve was prepared by dividing the LHI map into 18 successive susceptible classes on the basis of standard deviation and arranging them in descending

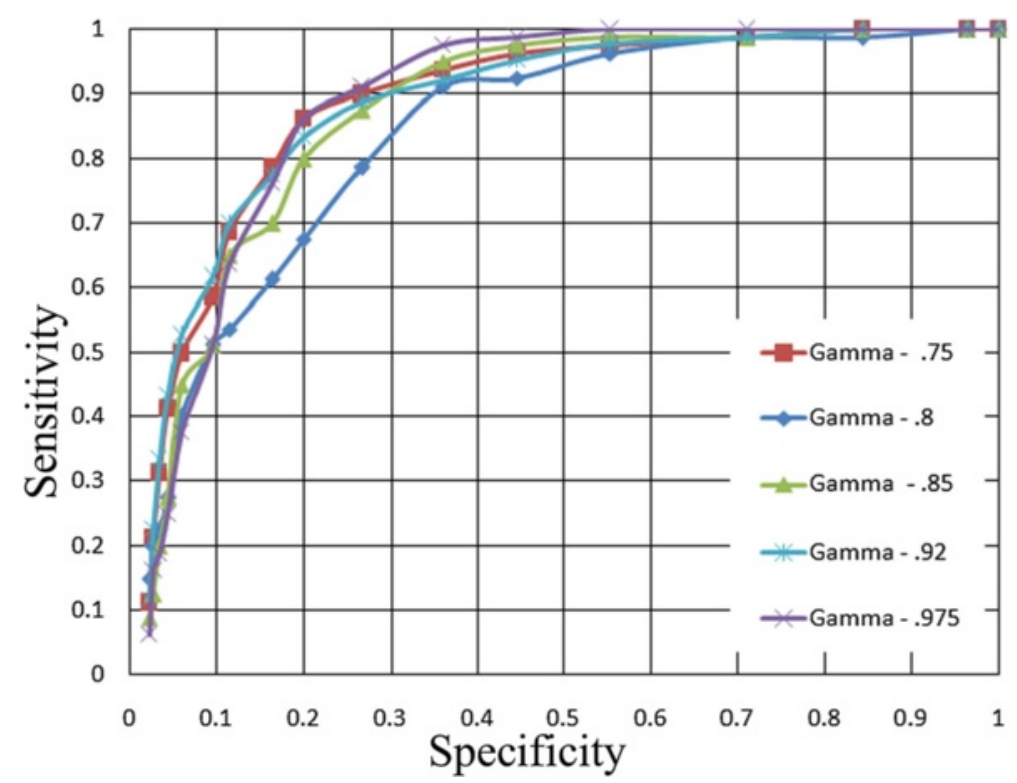

Figure 9 ROC graph representing curves for different gamma cases. Horizontal axis and vertical axis representing specificity and sensitivity respectively. 


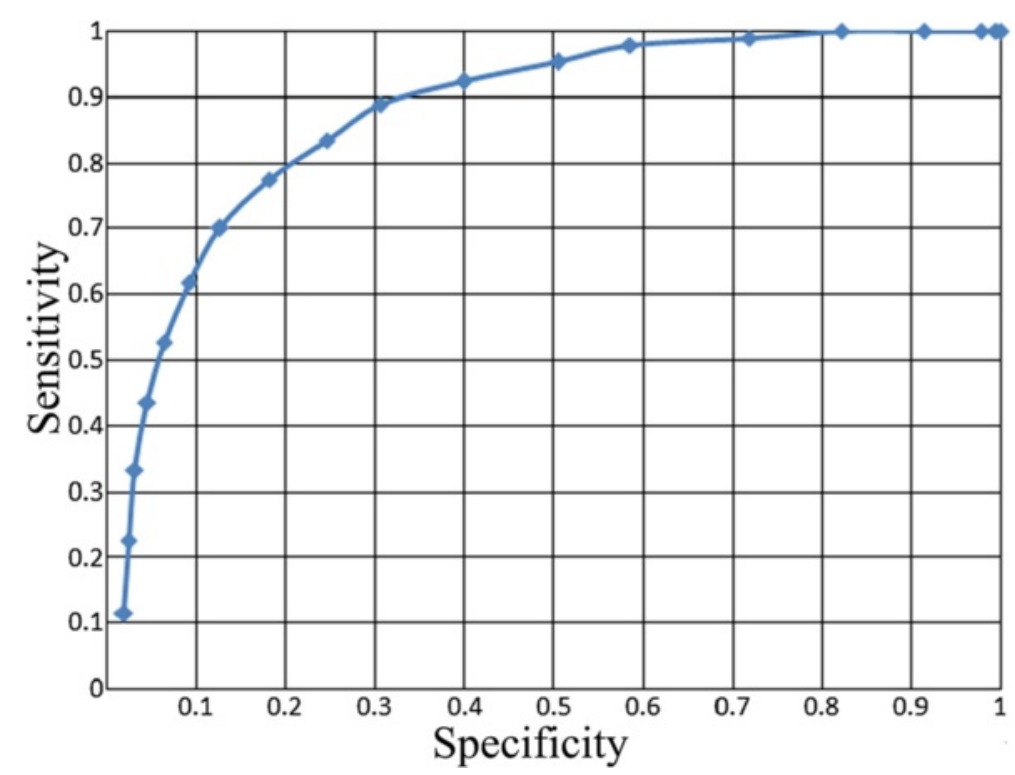

Figure 10 ROC curve of best suitable gamma (0.92) value.

order against the corresponding cumulative landslide area. Quantitative validation was performed by calculating the AUC value of ROC graph. AUC for 5 different gamma values are shown in Table 3 . Highest AUC value- 0.876 was found in the case of gamma- 0.975, so it can be said that accuracy of model was $87.6 \%$. In the same manner prediction accuracy of $85.23 \%, 82.11 \%, 80.245$ and $74.43 \%$ was observed in the case of gamma - 0.92, 0.85, 0.8, and 0.75 respectively. These results suggested good prediction accuracy of the model.

\section{Conclusions}

Fuzzy logic relations and fuzzy operation based landslide hazard zonation mapping have achieved acceptable results. Fuzzy membership values were determined by frequency ratio approach. Frequency ratio of each factor's attributes was determined. High frequency ratio values were observed for drainage buffer, relative relief and slope. Fuzzy gamma operator was successfully applied for the LHI map. Model suggested that higher gamma values $(0.92,0.975)$ yielded better prediction of LHZ than low gamma values $(0.75,0.8$. 0.85). Results had shown increasing tendency of hazard prediction corresponding to increasing gamma values. LHZ map indicated the importance to factors in landsliding.

Table 3 AUC values with respect to gamma( $\gamma)$ values

\begin{tabular}{lc}
\hline Gamma $(\gamma)$ & AUC values \\
\hline 0.975 & 0.876 \\
0.92 & 0.8523 \\
0.85 & 0.8211 \\
0.80 & 0.8024 \\
0.75 & 0.7443 \\
\hline
\end{tabular}

Among the slope classes, most of the high LHZ is observed in very high and high slope angle classes. Generally, in a terrain having high slope angle, the weight of the possible mobilized material under gravity will be more as compared to a moderate slope angle. Shear strength being same in both the cases, a steep slope with more mobilizing force may fail early. High hazard zone is observed in high and very high relative relief classes. High relative reliefs are surface manifestation of cliffs and ridges, which are often rendered unstable by the influence of triggering factors such as rainfall and earthquakes. Southern aspect of the study area, which is receiving excessive sun radiation and high rainfall, are observed under higher hazard zone categories. High hazard zones are also observed in the areas in closer proximity to drainages (drainage buffer) and it can be attributed to the stream bank erosion due to the river flow such as gulling, toe cutting which further leads to landslides. Lithology of the area belongs to different Formations and is represented by characteristic rock type, which might govern landslide incidence. High Hazard zones were observed in the rocks belonging to Kanchenjunga Formation as compared to Chungthang Formation. Alluvial sandy loamy soil has been observed at lower elevations along the drainage network and are not well compacted and are more prone to landslides. These areas are manifested in form of high hazard zone in the LHZ map. Model validity was performed using ROC curves. Smooth curves suggested good prediction results, whereas AUC values of ROC curves also indicated better prediction. Gamma: 0.92 was chosen for the final LHZ generation, because of smoothest ROC curve. Hence it can be concluded that landslide causative factor's integration using fuzzy logic has yielded good results for Lachung valley. Frequency ratio method for 
determination of fuzzy membership value has reduced subjectivity in the model. The final LHZ map $(\gamma=0.92)$ can be used for the planning of future infrastructure, settlement and ecological development in Lachung region.

\begin{abstract}
Abbreviations
Appl: Applied; Bull: Bulletin; Comput: Computer; Dis. Stu: Disaster studies; Eds: Editors; Geolnf: Geoinformatics; Geomat: Geomatics; Indus. Rese: Industrial Research; Inf: Information; Intel. Sys: Intelligent system; Int: Internatioal; Meta: Metamorphic; Observ: Observational; Obs: Observation; Petro: Petrology; Photogram: Photogrammetry; Quart: Quaternary; Rem. Sens: Remote sensing; Sci: Science; Soc: Society; Symp: Symposium.
\end{abstract}

\section{Competing interests}

The authors declare that they have no competing interests.

\section{Authors' contributions}

RA has carried out the detailed field investigations which included geological investigation, landslide identification along with contributions for the report writing of geological and physiographic conditions of the area. RK has carried out remote sensing data interpretation and conceptualization of methodology. KL has carried out geotechnical analysis of vulnerable slopes and field validation of land use land cover map. SP has carried out GIS analysis and lithological data interpretation. SN has helped in the preparation of ROC curve and also to draft the entire manuscript. All authors read and approved the final manuscript.

\section{Acknowledgements}

We acknowledge Lachung Hydro Power Pvt. Ltd., Teesta Hydro Power Pvt. Ltd. and Chungthang Hydro Power Pvt. Ltd., Noida, Uttarpradesh, India for their ancillary support for managing our stay during the course of field investigations and logistics. We also acknowledge Department $f$ Earth Sciences, IIT Roorkee, Uttarakhand, India for facilitating advanced softwares required to implement the research methodology.

\section{Received: 24 March 2014 Accepted: 12 November 2014}

Published online: 28 February 2015

\section{References}

Acharya SK, Shastry MVA (1979) Stratigraphy of eastern himalaya: geological survey of india miscellaneous publication. 41:49-67

Aleotti P, Chowdhury R (1999) Landslide hazard assessment: summary review and new perspectives. Bull Eng Geol Environ 58:21-44

Anbalagan R (1992) Landslide hazard evaluation and zonation mapping in mountainous terrain. Eng Geol 32:269-277

Anbalagan R, Chakraborty D, Kohli A (2008) Landslide hazard zonation (LHZ) mapping on meso-scale for systematic town planning in mountainous terrain. J Sci Indus Rese 67:486-497

Arora MK, Das Gupta AS, Gupta RP (2004) An artificial neural network approach for landslide hazard zonation in the Bhagirathi (Ganga) Valley, Himalayas. Int J Rem Sens 25:559-572

Ayalew L, Yamagishi H (2005) The application of GIS based logistic regression for landslide susceptibility mapping in the Kakuda-Yahiko Mountains. Central Japan Geomorphol 65(1/2):15-31

Begueria S (2006) Validation and evaluation of predictive models in hazard assessment and risk management. Nat Hazards 37:315-329

Bonham-Carter GF (1994) Geographic Information System for Geoscientists: Modelling with GIS, Pergamon/Elsevier Science Ltd., p 8

Brabb EE (1984) Innovative approaches to landslide hazard mapping. In: Proc 4th Int Symp Landslides, vol 1. Toronto, pp 307-324

Chauhan S, Sharma M, Arora MK, Gupta NK (2010) Landslide susceptibility zonation through ratings derived from Artificial Neural Network. Int J Appl Earth Observ Geoinf 12:340-350

Champatiray PK, Dimri S, Lakhera RC, Sati S (2007) Fuzzy-based method for landslide hazard assessment in active seismic zone of Himalaya. Landslides 4:101-111

Chi KH, Park NW, Lee K (2002) Identification of Landslide Area using Remote Sensing Data and Quantitative Assessment of Landslide Hazard. In: Proc IEEE Geosci Rem Sens Symp. Toronto Canada
Choi SW, Moon WM, Choi SG (2000) Fuzzy logic fusion of W-Mo exploration data from Seobyeog-ri, Korea. Geosci I 4(2):43-52

Chung CF, Fabbiri AG (2001) prediction models for landslide hazard Zonation using a fuzzy set approach. In: Marchetti M, Rivas V (eds) Geomorphology \& Environmental Impact Assesment. Balkema Publishers, Rotterdam, pp 31-47

Clerici A, Perego S, Tellini C, Vescovi P (2002) A procedure for landslide susceptibility zonation by the conditional analysis method. Geomorphology 48:349-364

Dahal RK, Hasegawa S, Nonomura S, Yamanaka M, Masuda T, Nishino K (2008) GIS-based weights-of-evidence modelling ofrainfall-induced landslides in small catchments for landslide susceptibility mapping. Environ Geol 54(2):314-324

Dahal RK, Hasegawa S, Yamanaka M, Dhakal S, Bhandary NP, Yatabe R (2009) Comparative analysis of contributing parameters for rainfall-triggered landslides in the Lesser Himalaya of Nepal. Environ Geol 58(3):567-586

Dahal RK, Hasegawa S, Bhandary NP, Poudel PP, Nonomurac A, Yatabe Y (2012) A replication of landslide hazard mapping at catchment scale. Geomat Nat Hazards Risk doi:10.1080/19475705.2011.629007

Das I, Sahoo S, Van Westen CJ, Stein A, Hack R (2010) Landslide susceptibility assessment using logistic regression and its comparison with a rock mass classification system, along a road section in the northern Himalayas (India). Geomorphology 114:627-637

Das I, Stein A, Kerle N, Dadhwal (2012) Landslide susceptibility mapping along road corridors in the Indian Himalayas using Bayesian logistic regression models. Geomorphology 179:116-125

Deleo JM (1993) Receiver operating characteristic laboratory (ROCLAB): software for developing decision strategies that account for uncertainty. In: Proc. 2nd Int. Sym. uncertainty modelling and analysis. Computer Society Press, College Park, 318-325

Ercanoglu M, Gokceoglu C (2002) Assessment of landslide susceptibility for a landslide-prone area (north of Yenice, NW Turkey) by fuzzy approach. Environ Geol 41:720-730

ESRI FAQ (2012) What is the Jenks Optimization Method?., http://support.esri. $\mathrm{com} / \mathrm{en} /$ knowledgebase/techarticles/detail/26442

Ghosh S, Carranza EJM, van Westen CJ, Jetten VG, Bhattacharya DN (2011) Selectingand weighting of spatial predictors for empirical modeling of landslide susceptibilityin Darjeeling Himalaya (India). Geomorphology 131:35-56

Hutchinson JN (1995) Landslide hazard assessment. In: Proc VI Int Symp on Landslides, vol 1. Christchurch, pp 1805-1842

Gupta P, Anbalagan R (1997) Landslide hazard zonation (LHZ) and mapping to assess slope stability of parts of the proposed Tehri dam reservoir India. Quart J Eng Geol 30:27-36

Gupta RP, Joshi BC (1990) Landslide Hazard Zonation using the GIS Approach - A case Study from the Ramganga Catchment Himalayas. Eng Geol 28:119-131

Gupta RP, Saha AK, Arora MK, Kumar A (1999) Landslide Hazard Zonation in a part of the Bhagirathi Valley Garhwal Himalayas using integrated remote sensing-GIS. Himalayan Geol 20:71-85

Gupta RP, Kanungo DP, Arora MK, Sarkar S (2008) Approaches for comparative evaluation of raster GIS-based landslide susceptibility zonation maps. Int J App Earth Obs Geoinform 10:330-341

Guzetti F, Carrara A, Cardinali M, Reichenbach P (1999) Landslide hazard evaluation: a review of current techniques and their application in a multi-scale study, central Italy. Geomorphology 31:181-216

Guzzetti F, Reichenbach P, Cardinali M, Galli M, Ardizzone F (2005) Probabilistic landslide hazard assessment at the basin scale. Geomorphology 72:272-299

Guzzetti F, Reichenbach P, Ardizzone M, Cardinali M, Galli M (2006) Estimating the quality of landslides susceptibility models. Geomorphology 81:166-184

Kanungo DP, Arora MK, Sarkar S, Gupta RP (2006) A comparative study of conventional, ANN black box, fuzzy and combined neural and fuzzy weighting procedures for landslide susceptibility Zonation in Darjeeling Himalayas. Eng Geol 85:347-366

Kanungo DP, Arora MK, Sarkar S, Gupta RP (2009a) Landslide Susceptibility Zonation (LSZ) Mapping - A Review. J South Asia Dis Stu 2:81-105

Kanungo DP, Arora MK, Sarkar S, Gupta RP (2009b) A fuzzy set based approach for integration of thematic maps for landslide susceptibility zonation. Georisk 3(1):30-43

Kayastha P, Dhital M, De Smedt F (2013) Application of the analytical hierarchy process (AHP) for landslide susceptibility mapping: a case study from the Tinau watershed, west Nepal. Comput Geosci 52:398-408

Kundu S, Saha AK, Sharma DC, Pant CC (2013) Remote Sensing and GIS Based Landslide Susceptibility Assessment using Binary Logistic Regression Model: A Case Study in the Ganeshganga Watershed, Himalayas. J Indian Soc Rem Sens 41(3):697-709 
Lee S, Choi J, Min K (2002) Landslide susceptibility analysis and verification using the Bayesian probability model. Environ Geol 43:120-131

Lee S, Talib JA (2005) Probabilistic landslide susceptibility and factor effect analysis. Environ Geol 47:982-990

Lee S, Sambath T (2006) Landslide susceptibility mapping in the Damrei Romel area, Cambodia using frequency ratio and logistic regression models. Environ Geol 50:847-855

Lee S, Pradhan B (2007) Landslide hazard mapping at Selangor, Malaysia using frequency ratio and logistic regression models. Landslides 4:33-41

Mathew J, Jha VK, Rawat GS (2007) Weights of evidence modelling for landslide hazard zonation mapping in part of Bhagirathi valley, Uttarakhand. Curr Sci 92:628-638

Mathew J, Jha VK, Rawat GS (2009) Landslide susceptibility zonation mapping and its validation in part of Garhwal Lesser Himalaya, India, using Binary Logistic Regression analysis and receiver operating characteristic curve method. Landslides 6:17-26

Nagarajan R, Mukherjee A, Roy A, Khire MV (1998) Temporal remote sensing data and GIS application in landslide hazard zonation of part of Western Ghat, India. Int J Rem Sens 19(4):573-585

Ohlmacher GC (2007) Plan curvature and landslide probability in regions dominated by earth flows and earth slides. Eng Geol 91:117-134

Pachauri A, Pant M (1992) Landslide hazard mapping based on geological attributes. Eng Geol 32(1-2):81-100

Pardeshi DS, Autade ES, Pardeshi SS (2013) Landslide Hazard Assessment: Recent Trends and Techniques., doi:10.1186/2193-1801-2-523

Poudyal CP, Chang C, Oh H, Lee S (2010) Landslide susceptibility maps comparing frequency ratio and artificial neural networks: a case study from the Nepal Himalaya. Environ Earth Sci 61:1049-1064

Pourghasemi HR, Goli Jirandeh A, Pradhan B, Xu C, Gokceoglu C (2013) Landslide susceptibility mapping using support vector machine and GIS. J Earth Syst Sci 122:349-369.

Pradhan B (2010) Application of an advanced fuzzy logic model for landslide susceptibility analysis. Int J Comput Intel Sys 3(3):370-381

Pradhan B, Lee S (2010) Delineation of landslide hazard areas on Penang Island, Malaysia, by using frequency ratio, logistic regression, and artificial neural network models. Environ Earth Sci 60:1037-1054

Pradhan B, Lee S, Buchroithner M (2010) Remote sensing and GIS-based landslide susceptibility analysis and its cross-validation in three test areas using a frequency ratio model. Photogram Fernerkundung Geolnf 1:17-32

Ray KK (1976) A review of the geology of the Darjeeling- Sikkim Himalayas. In: Himalayan Geological Seminar. New Delhi, pp 13-17

Saha AK, Gupta RP, Arora MK (2002) GIS-based landslide hazard zonation in a part of the Himalayas. Int J rem sens 23(2):357-369

Saha AK, Gupta RP, Sarkar I, Arora MK, Csaplovics E (2005) An approach for GIS-basedstatistical landslide susceptibility zonation with a case study in the Himalayas. Landslides 2:61-69

Sarkar S, Kanungo DP (2004) An integrated approach for landslide susceptibility mapping usingremote sensing and GIS; Photogrammetric. Eng Rem Sens 70(5):617-625

Sinha-Roy S (1982) Himalayan Main Central Thrust and its implications for Himalayan inverted metamorphism. Tectonophysics 84:197-224

Soeters R, Van Westen CJ (1996) Slope stability: recognition, analysis and zonation. In: Turner A, Shuster R (eds) Landslides: investigation and mitigation. National Academy Press, Washington D C, pp 129-177

Van Westen CJ, Van Asch TWJ, Soeters R (2006) Landslide hazard and risk zonation why is it still so difficult? Bull of Eng Geol and Environ 65:167-184

Varnes DJ (1984) Landslide Hazard Zonation: a review of principles and practice; UNESCO. Nat Hazards 3:61

Yalcin A (2008) GIS-based landslide susceptibility mapping using analytical hierarchy process and bivariate statistics in Ardesen (Turkey): comparisons of results and confirmations. Catena 72:1-12

Yilmaz I (2009) Landslide susceptibility mapping using frequency ratio, logistic regression, artificial neural networks and their comparison: a case study from Kat landslides (Tokat-Turkey). Comput Geosci 35(6):1125-1138

Zadeh LA (1965) Fuzzy sets. Inf Control 8:253-338

Zimmermann HJ (1996) Fuzzy set theory and its applications. Kluwer Academic Publishers, Springer, p 435

\section{Submit your manuscript to a SpringerOpen ${ }^{\odot}$ journal and benefit from:}

- Convenient online submission

- Rigorous peer review

- Immediate publication on acceptance

- Open access: articles freely available online

- High visibility within the field

- Retaining the copyright to your article

Submit your next manuscript at $>$ springeropen.com 